\title{
ONS ERFENIS: DIE BELYDENISSKRIFTE
}

U moet my vergun om te begin met Ps. $16: 6:$ :Die meetsnoere het vir my in lieflike plekke geval, ja, my erfenis is vir my mooi". U hoor hier 'n waardering van „my erfenis" wat opwel uit die binneste van 'n gelowige, wat seker weet „Die HERE is die deel van my erfenis" en dankbaar uitroep: „My erfenis is vir my mooi". Die digter is in vervoering en hy kan sy woorde nie inhou nie. Dit is nie maar 'n emosionele opwelling nie, maar ' $n$ juiste waardering. Hy vereenselwig hom met verstand, gevoel, hart en kragte met hierdie uitroep.

Ek neem aan dat u wil hê dat ek iets van hierdie jubel oor ons mooi erfenis aan u moet oorbring, omdat ons 'n Universiteit vir Christelike Hoër Onderwys is, en hierdie mooi erfenis ook ons liefde het. Dit is gepas dat ons by die Vierhonderjarige fees van een van ons Belydenisskrifte ook hierdie huldigingswoord spreek.

\section{Watter waarde ken ons aan 'n Belydenisskrif toe?}

Dit is skynbaar 'n onbelangrike vraag en tog was daar nog nimmer eenstemmigheid hieroor nie. Dit gaan nie maar net daarom dat sommige kringe meen dat ons geen belydenisskrif behoort te hê nie. So 'n negatiewe mening kan wel volkome uit Gods Woord geloënstraf word. Van die vroegste tye af het die kerk van Christus 'n belydenis gehad, wat die kenmerkende naam homologia gehad het, wat beteken eendersluidende sprake. Wat meer is, die belydenis was 'n objektiewe weergawe van die inhoud van wat subjektief hely word. Aan die begin was dit wel nog nie opgeteken nie, maar is in mondelinge oorlewering herhaal en kon dit weergegee word.

Die Heilige Skrif:

In Gods Woord word in Hebr. 4 : 14 vermaan: „Laat ons 
die belydenis vashou". Die wyse waarop dit meegedeel word, laat ons verstaan dat ons hier 'n geykte bepaalde homologia het wat gehandel het oor Christus en sy werk. Hoofsaak is dat hier iets objektiefs was en nie net iets subjektiefs nie. Immers in mens kan toy nie aan iets vashou wat nie buite jou bestaan nie.

Die Brief aan Timotheus is hiervan vol en roep telkens lerug tot iets bekends, iets wat sonder twyfel vasgestaan het in die gemeente. In 1 Tim. $6: 3$ is daar sprake van „die leer wat volgens die godsaligheid" is, en wat as toetssteen aangewend kan word om die gesonde leer mee vas te stel. Ook hier is buite twyfel 'n vaste belydenis bedoel. Buite twyfel word Timotheus ook opgeroep om as persoon vas te staan in 'n bekende belydenis. Ons dink hier aan die bekende woorde uit 1 Tim. $6: 12$ en 13: "Stry die goeie stryd van die geloof, gryp na die ewige lewe, waartoe jy ook geroep is en die goeie belydenis voor baie getuies afgelê het. Ek gebied jou voor die aangesig van God wat aan alle dinge die lewe gee, en van Christus Jesus wat voor Pontius Pilatus die goeie belydenis: betuig het".

Hierdie Brief aan Timotheus is vol van hierdie duidelike uitsprake en ons verwys nog net na die vermaning aan Timotheus „Bewaar jou pand". wat in duidelike teëstelling staan tot die valse belydenis wat sommige gedoen het. Dieselfde woorde vind ons weer in 2 Tim. 1 : 14: „Bewaar jou goeie pand".

Hierdie objektiewe belydenis wat gelees. bestudeer, aanvaar kan word en wat waardeer kan word as 'n erfenis wat mooi is, moet nie net buite my bestaan nie, maar ook bloed van my bloed en been van my been word. Inderdaad is daar so iets as ' $n$ belydenis- en 'n belydende kerk. Ook dit word duidelik deur Gods Woord aan ons gestel. In Matth. 10:32 hoor ons van so 'n persoonlike belydenis: ..Elkeen dan wat My sal bely voor die mense. hom sal Ek ook bely voor my Vader wat in die hemele is". As die gemeente nie bely nie, het dit stom geword en kan daar geen krag van uitgaan nie. Immers die ware geloof moet ook toestem alles wat God in sy Woord aan ons geopenbaar het. Hierdie toestemming stel die eis dat ons moet bely dat die Woord waaragtig is. In Rom. 10: 9 maan die apostel Paulus: ,As jy met jou mond 
die Here Jesus bely en met jou hart glo dat God Hom uit die dode opgewek het, sal jy gered word; want met die hart glo ons tut geregtigheid en met die mond bely ons tot redding".

\section{Die geskiedenis:}

As Polman deur die geskiedenis heen 'n kort wandeling neem met hierdie ondersoek as motief, nl. hoe oordeel die zeskiedenis oor die waarde van die belydenisskrifte? groepeer hy die oordeel onder vier hoofde. wat ons korteliks hier wil weergee:

Uit hierdie diskussie is dit duidelik dat daar voortdurend standpunt ingeneem is en dat geeneen van die kerke of gemeenskappe onverskillig durf staan het nie. Die Belydenisskrifte het ' $n$ belydenis ontlok.

a. Rome het 'n uiters rigoristiese opvatting en neem sy simbole op as dekrete. Die onfeilbaarheid van sy konsilies, van die pous as hy ex cathedra spreek, belet elke gedagte dat besluite aan revisie onderwerp kan word. Hier word nie gevra om gehoorsaamheid nie, maar onderwerping. Die gewete word gebind en eintlik word die Heilige Skrif aan die Belydenis onderwerp. Die kerk besit die Skrif en was vóór die Skrif en die kerk verklaar die Skrif, hou die eksegese in sy hand. Niemand het die reg om 'in ander verklaring van die Sikrif te gee as die wat die kerk in sy dekrete gegee het nie. Dus: die Skrif is aan die Belydenis onderworpe. En nou kan uns begryp dat ons hier 'n oorwaardering het van die waarde van die Belydenisskrifte. Niks anders kan verwag word as tirannie en verslawing van die gees nie. As Gods Woord onderwerp word aan menslike beslissinge, hoe goed ook al bicdoel. is die hevrydende krag gebreek. Dan moet daar lirandstapels ronk en kom daar vervolging. Dit is alleen Gods Woord wat ons hoed vir hierdie vorm van vryheidsroof en konsiënsied wang.

Onfeilhare dekrete ... dit is in totale oorbeklemtoning van die waarde van belydenisskrifte en 'n oorwaardering van $\checkmark y$ plek vir enige kerklike gemeenskap.

b. Tipies vir die sekites en hieronder wel die doopsgesindes, is ' $n$ weersin teen enige vorm van belydenisskrif. Vandag is hierdic houding wat betref die Apostoliese Geloofsen- 
ding in Suid-Afrika al gewysig, m.i. nie omdat die oorspronklike houding verander het nie, maar om meer voorregte te verkry en 'n meer kerklike kleur te bekom. Inderdaad het hulle, met die Nederlandse Geloofsbelydenis as basis, 'n eie belydenisskrif opgestel, met die doel om uitsaaivoorregte te bekom en het selfs aansoek gedoen om erkenning as kerk.

Die eie sektariese houding is hierin tog om elke belydenis an te voel as 'n binding, 'n knellende ketting. Hulle wil die vryheid hê om slegs die Skrif as grond te hê. Hulle gevoele word ook wel uitgedruk in die woorde dat slegs die Skrif gesag het en dat enige menslike formule afbreuk doen aan die outoriteit van die Skrif. Dit kan selfs die Skrif verswak, sodat ons 'n ander boek langs die Skrif, gelykstaande of selfs belangriker as die Skrif gaan waardeer. Tegelyk word in hierdie kring die vrees gekoester dat enige Konfessie aanleiding kan gee tot versplintering, omdat 'n hele gemeenskap nie eenstemmig kan word oor alle punte van 'n belydenis nie. Inderdaad is elke Konfessie natuurlik 'n begrensing van die wydlopendheid van die inhoud van ons geloof. Dit bring ook mee dat belyders hulle moet voeg na die Belydenis, en dit gaan soms baie moeilik in hierdie kring van entoesiaste, waar daar eweveel opvattinge is as wat daar lede is.

c. Ook by Remonstrante en ander vrysinniges vind ons dieselfde trekke, wat aangedui kan word as belydenisfobie. Bekend is die slagwoord: geen formuliergesag, slegs Skrifgesag. En tog is dit nie 'n egte houding nie, want Skrifgesag word hier ook nie al te eng geneem nie. Eintlik is dit slegs 'n poging om tot vrysinnigheid te kom, gesagloosheid te omhels en die Skrif self ook slegs as dekmantel te gebruik. Ons moet dus hier net die teenoorgestelde konstateer as by Rome: 'n totale onderskatting van die Belydenisskrifte.

d. 'n Vierde opvatting vind ons by diegene wat wel entnesiasties is oor Belydenisskrifte en wat geesdriftig dit wil aanvaar, maar slegs as simbole, maar nie met bindende gesag hulle beklee nie. Belydenisskrifte is hier slegs tekens van oorwinning, simbole van die triomftog om weer te gee wat nou al bereik is. By hierdie groep mag gereken word nie net Remonstrante en Liberaliste wat toegee dat daar wel resultaat kan wees na eeuelange wetenskaplike beoefening en dat kerke dan tot sekerheid kan kom aangaande sekere kardinale 
leerstukke nie, maar moet ook gereken word diegene wat op die sg. quatenus-standpunt staan. In sover as wat belydenisskrifte in Gods Woord bevestig word, mag hulle en moet hulle aanvaar word, maar dit is die uiterste wat van hulle gesê en verwag kan word. Belydenisskrifte is dus nie geldige simbole vir 'n sekere kerk nie, maar konfessies vir die tyd waarin hulle opgestel is.

Hierdie dubbelslagtige houding kan duidelik onderken word as ons saam met die huldiging van die Belydenisskrifte as pragtige wimpels en vlae van 'n optrekkende strydende kerk. ook moct wys op die belydenisvrees. Niemand is meer bedag op die gevare wat binding aan die Belydenisskrifte meebring. as juis alle vorme van Remonstrantisme nie. Daar moet gewaak word om nie blywende outoriteit aan hulle toe te skryf nie, hulle nie te maak tot regulae fidei nie. Hulle is nie fonteine waaruit geput moet word of beginsels waarop ons iets mag bou of waarop uns ons mag beroep nie. Eintlik moet hulle net daar wees as historiese gegewenhede wat in 'n sekere tyd as waar en vas bevind is. Hierdie rigting wys op die historiese feite dat sekere belydenisskrifte deur eeue heen vasgestaan het sonder die minste verandering en selfs in dae van bittere stryd ongedeerd daaruit gekom het. Die neiging is om sodanige konfessies te omklee met buitengewone outoriteit, sodat dit hykans gelykstaan met Gods Woord. Vandaar die voortdurende vrces dat konfessies kettings kan word wat gewetens bind. Die sg. quia-standpunt word juis aangevoel as so 'n binding. Hierdie standpunt maak formuliere tot mure wat só hoog is dat dit afsluit, grense waaroor ons mekaar nie die hand kan reik nie. 'n Ortodokse handhawing van so 'n binding moet danrtne lei dat almal wat nie akkoord gaan nie, beskou word as uitgesluit van die saligheid, as diegene wat God en sy Woord nie vress nie. Dit moet voer tot voortdurende ketterjag.

Ons sou meer nor hierdie Remonstrantse standpunt kon sê, maar wil slegs daarop wys dat Remonstrantisme nie ondergegaan het in die lie eeu nie. Hy is nie alleen bekend by diegene wat nie huiwer om hulleself Remonstrants te noem nie, maar ook by diegene wat eintlik om die Konfessie heenloop en dit nie meer as objektiewe Belydenisskrif wil erken nie. Modern is vandag om te bly spreek van die sogenaamde 
aktualiteit, die dinamiese, die wordende. Alles wat enigsins die blywende kenmerk vertoon word beskinder as staties, verouderd, reeds veroordeeld. Konfessies moet leef in die volkshart, word voortdurend opnuut gevorm. Nie dat die oue verander word of gepoog word om veranderinge teweeg te bring nie. Daarvoor is daar te veel agting vir die tradisie, vir die gewese stukke wat in die argief nog belangrike studiestukke vir die Dogmageskiedenis kan bly. Hande af van die simbole van die ve rlede. Maar wat van die hede?

Sonder om iets van die verlede te herroep, moet deur hervorming en revisie steeds tot suiwerder uitdrukking van die belydenis gekom word. Voorts word ampsdraers en proponente gebind, nie aan ' $n$ belydenis nie, maar aan ", het belyden der Kerk". Hier het ons die dinamiese en wordende belydenis.

Waarom so 'n vrees vir 'n Belydenis wat uit Gods Woord saamgestel word en die volle gees van die Skrif adem?

e. En so kom ons dan by die antwoord uit Gereformeerde kring. Die antwoord wat gegee word op bogenoemde vraag is: die vraag kan nie wees of kerke in hul belydenis kan dwaal nie, maar of hulle werklik gedwaal het. Telkens mag belydenisskrifte ondersoek word deur wettige kanale en kan nie net gewysig word nie, maar moet gewysig word wanneer uit Gods Woord bewys kan word dat daar verkeerde gedagtes in vervat is.

Op so 'n wyse word dan telkens duidelik bepaal dat Gods Woord die enigste waaragtige Woord is, die enigste reël vir ons geloof. Belydenisskrifte het ook geen eie outoriteit nie. maar het afgeleide gesag. Daardeur word die Belydenisskrifte nie gedegradeer tot 'n blote vlag waaronder die skip van die kerk seil nie, tot 'n menslike vinding wat genadeloos kan tiranniseer oor lidmate nie; veeleer is dit 'n waarborg dat slegs Gods Woord en mitsdien God self koninklike reg het oor Gods erfdeel.

Maar dan volg die volgende vraag klaarblyklik: het ons dan nie aan Gods Woord genoeg nie? Waarom dan benewens Gods Woord nog 'n Belydenisskrif? Is dit onnodige en onwenslike duplikasie, waardeur die menslike element tog as outoritatiewe krag ingebring word? 
Hierop het Groen van Prinsterer seker 'n afdoende antwoord gegee, wat ons korteliks wil saamvat:

(1) Van die gesag van Gods Woord kan en wil ons niks afding nie en sy enige plek moet in alle omstandighede gehandhaaf word. As alleen Gods Woord egter tot reël van prediking en onderwys in die kerk gegee word, word die kerk prysgegee aan indiwidualisme en subjektiwisme. Dan kan elkeen maar sy eie opvatting hê van die Skrif en elke ketter sy letter. Groen is hieroor nie te spreke nie, want hy voorsien 'n Babelse spraakverwarring van meninge, want alle meninge oor Gods Woord is dan volkome gelyk. Nou is daar geen akkoord van gemeenskap nie, niks wat meer saambind nie. Die kerk kan dan nie meer sê: "Ons glo en bely" nie, maar slegs „Ek glo en bely”. So het die kerk die beeld van droë sand, sonder enige binding, is dit 'n menigte en geen gemeente nie.

(2) Die formulering van die geloofstukke in Formuliere is nie 'n blyk van wantroue in die genoegsaamheid van Gods Woord nie, maar juis ' $n$ verdere bewys van die hartelike voorneme om vas te hou aan Gods Woord. „Zij zijn een opteekening van blijvende resultaten, het bewijs der overwinning, de langzaam gerijpte vrucht eener ontwikkeling van Bijbelonderzoek en geloofskracht, welke door de onmiskenbare werking van de Goddelijke zegen de overhand behaald heeft. De Formulieren zijn een reeks van gedenkteekenen der strijdende kerk, onwraakbare getuigen van het geloof eenmaal den heiligen overgeleverd, schakels van dezelfde keten, mijlpalen van éen weg, waardoor het afgelegde deel aangeduid wordt, niet om te blijven staan, maar om voort te gaan in de rigting, waarin de gemeente met onbedriegelijke strekking geleid werd. $\mathrm{Zij}$ zijn gedenkschriften van haar geloof, de belijdenis, die zij als gemeente van den levenden God ter eere van $Z_{i j n}$ heiligen Naam heeft afgelegd. Met volledige erkenning van den Bijbel als eenige regel des geloofs is de kerk met deze geloofsregel tot geloofseenheid gekomen".

(3) Maar 'n Geloofsbelydenis mag nie onaangeraak bly staan, asof dit vergoddelik kan word en volmaaktheid daaraan toegeken word nie. Tog moet elkeen oppas hoe hy daarop 
voortbou. Die deur word nie wawyd oopgeset om maar stukke uit te sny en weg te werp en ander by te pas nie. Belydenisstukke is nie soos ou skoene wat maar uitgetrek en vervang kan word nie. Nimmer mag dit in toto oorweeg word nie. Nuwe en oue spreek hier dieselfde gees en nuwe stukke moet aansluit by die oue. As hierbo gestel is dat die konfessies nie bedoel is om te bly staan nie, maar om voort te gaan in dieselfde rigting, moet enige voortgang in die teken staan van waaksaamheid, in die gees van Luk. 12 : 35--40. Daar het ons die gelykenis van die waaksame dienskneg, wat oor sy heer se huis waghou. Die teëstelling kom duidelik in hierdie gelykenis na vore tussen die dienskneg wie se heupe omgord en die lampe aan die brand is en wat die huisheer wakker vind as hy kom, al geskied dit in die tweede of derde nagwaak. Die ander, ontroues, is nie net die wat met ontrouheid begin drink en slaan onder die diensknegte nie, maar sekerlik ook die wat nie in dieselfde gees bly, $\mathrm{nl}$. om wakker en besig te wees nie. Dit is ook hulle wat meen dat dit laat geword het, en nou kan die deure maar gesluit word en die ligte gedoof word. Dit is die diensknegte wat 'n slot- en grendelkompleks het, baie meer bekommerd is oor afsluitingswerk as om besig te wees.

'n Kerk veronderstel dat sy belydenisskrifte in blywende aard het. Enige wysiginge wat daaraan gebring word, moet nie die kenmerk dra van diensknegte wat elke vorm van diensknegstrou mis en daarom wil breek nie, maar moet die wakker gees dra van die wat waardeer, wat helderder lig daaroor aansteek. Moet dus nie finaal afsluit en in die museum van die verlede plaas nie, maar staan daaroor wag en laat die voortgang ' $n$ bevestiging wees van die verlede en ' $n$ ontwikkeling langs wettige kanale, voortbouend op die regte en egte grondslae, puttend uit Gods ewige Woord.

Vanweë die groot gevaar om die bekende Geloofsbelydenis, met die oog op 'n m.i. valse ekumenisiteitsgeroep te verdiskonteer en slegs op 'n paar slagwoorde te konsentreer, moet 'n baie ferme standpunt ingeneem word en moet verklaar word dat die Geloofsbelydenis 'n organisme is, waaruit nie lukraak dele kan weggeneem en gedegradeer word tot minder belangrik en ander tot meer fundamenteel nie. 
II. Welke rol speel interkerklike verhoudinge oor die belydenisopvatting?

In Nederland het kort gelede 'n al hoe sterker strewe na vore gekom, nl. om die eenheid van die kerk te beklemtoon en wel vanweë die Skriftuurlike grond van Joh. $17: 11$ : „... sodat hulle één kan wees, net soos Ons" en ook Joh. 17 : 21 : „Dat almal één mag wees net soos $U$, Vader, in My en Ek in U; dat hulle ook in Ons één mag wees".

Vanweë die groot kerklike gedeeldheid, ook genoem pluriformiteit, wat as sonde aangevoel word en iets waaroor rou bedryf moet word, kom dan 'n nuwe gees na vore. Geloofsbelydenisstukke word ervaar as verdelende grense, afbakeninge wat gelowiges uiteen hou, nie saam laat Nagmaal gebruik nie en ook nie saam laat kom onder die erediens nie. Daar kan geen kanselruil plaasvind nie, en die geroep om 'n nuwe dag word al luider.

Hiertoe het meegewerk die afgelope wêreldoorlog, toe persone in dieselfde ellende dikwels saamgekom het, en nou word gepoog om die eenheid onder die verdrukkende omstandighede te bestendig. Daar is toe iets aangevoel van die eenheid waarvan Christus gespreek het in Joh. 17.

Hierna het ontwaak die geweldige internasionale saambinding van volke onder een dak, wat verwerklik geword het in die V.V.O. Allesins word gepoog om die kontak tussen die volkere te behou. Die kerke het gevoel dat dit ook hulle roeping is. Die Ekumeniese bewegings het sterker geword en algemeen het ' $n$ sterk gevoel na vore gekom om met mekaar in gesprek te kom. Kerke van verskillende belydenis is verbind in bv. die Presbiteriaanse Alliansie, die Wêreldraad van Kerke, die Internasionale Raad van Christelike Kerke en andere. Hierdie Rade van kerke sou nie inbreuk maak op één kerk se belydenis nie. Vir aansluiting is alleen gevra dat bely moet word in één enkele formule, wat die Wêreldraad van Kerke betref: Jesus Christus as Heer en Heiland, later uitgebrei om Hom ook te bely as Saligmaker. Dit, so is aangevoel, is die belangrikste en al die ander belydenisstukke is hieraan onderhorig. Van die ander Rade was meer behoudend in hul standpunt en het probeer saamvoeg wat volgens bepaalde Belydenisse bymekaar behoort. 
Dit het weer gegaan om die belydenis. Daar moet 'n belydenisgrondslag gesoek word waarop kerke met mekaar kan saamspreek. Vandaar dat elkeen van die Ekumeniese bewegings, al is dit net ' $n$ enkele, dan tog nog 'n belydenisgrondslag het. Daar is algemeen begin spreek dat kerke in die loop van eeue tog hul Belydenisskrifte gewysig het, dat daar dikwels tot veranderinge gekom is, en dat dit niks ongewoons is om te soek na die gemeenskaplike belyde, gereduseer tot die kardinale. wat aanvaarbaar is vir alle kerke nie.

Myns insiens het die Ekumeniese bewegings - en ek wil nie een uitsonder nie -... meegewerk tot 'n ander uitsig oor kerke se Belydenisskrifte. Miskien het die kerke self ook meegewerk om die Belydenisskrifte te laat reduseer, omdat hulle nie telkens die taak onderneem het om die bepaalde Belydenisstukke grondig te ondersoek as hulle vind dat 'n duideliker formulering gewens is nie. Ons het pogings gevind, soos bv. deur die Amerikaanse kerke, wat nie die moed gehad het om die teks van 'n betrokke artikel te wysig nie, maar aangevoel het dat hulle nie meer met die artikel kan saamstem nie. Hulle het toe per besluit van die Sinode 'n voetnoot aangeheg aan die artikel. So iets doen veel meer kwaad as goed. Bevoetnoting bring die gevaar mee dat die toevoeging onderaan die eintlike belydenis is, en nie meer die oorspronklike artikel nie. Die appendix het die hart geword in die liggaam van die Belydenis.

En voorts het daar van die kerke al te dikwels gekom 'n halfslagtige verdediging van die Belydenis. Berkouwer moes al meer as eens daarop wys dat sulke poginge eintlik daarop neerkom dat die kerk sy Belydenis wil bewys. Die wetenskaplike Dogmatiek moet nimmer probeer om verstandbewyse aan te voer ter verklaring van die Konfessie nie, omdat dit al dadelik die skyn gee asof na buiteskriftuurlike middels gesork word ter stawing van dit wat verstandsmatig saamgestel is.

Verder moet die Gereformeerdes nie die indruk gee asof hulle met hul Belydenisskrifte altyd op die verdediging is nie. Dit is slegs 'n terugtrekkende leër wat nog altyd agterhoedegevegte lewer. Die bekende Belydenisskrifte is sowel wat hul historiese agtergrond betref, as wat hul inhoud betref, veelmeer 'n wêreldoorwinnende as 'n kapitulerende leërmag. So 'n verdediging gee geen vertroue wat op sy konfessionele 
skanse terugval, maar tegelyk bely dat die skanse vol barste is en geen veiligheid meer bied nie. Dit is 'n angstige verdediging, vol vrees. So het Paulus nie gestaan op die Areopagus nie. En wat het hierdie apostel gedoen? Met die wysgere geredetwis en op hulle grondslag gaan staan? Nee, Paulus verdedig nie in daardie $\sin$ nie. Hy gee aan ons die enigste grondslag van egte verdediging nl. verantwoording. Só het Paulus hom verdedig as hy in sy prediking aangeval word. Hy het die moed gehad -... en ook Petrus en Judas en Jakobus en Johannes -... om met verantwoording uit die Skrif en Skrifverband, alle dwalinge af te weer en die Evangelie in sy kern as onaantasbare waarheid te stel, in waarheid wat onweerlegbaar is en dus alleen kan vrymaak. Christus het self aan ons die verantwoording gegee. Ons verwys bv. na die spottende aanmerking teen Hom gemik in Luk. $11: 15$ : „Maar sommige van hulle sê: deur Beëlsebul, die owerste van die duiwels, dryf Hy die duiwels uit". Sy verantwoording tref raak: "Elke koninkryk wat teen homself verdeeld is, word verwoes; en in huis wat teen homself is, val. En as die Satan ook teen homself verdeeld is, hoe sal sy koninkryk bly staan?" (vss. 17, 18).

Die verantwoording sny nie net alleen met striemende kritiek as die dwase logika aangedui word nie, maar is nog raker wanneer dit só lui: „Julle dwaal, omdat julle die Skrifte nie ken nie en ook nie die krag van God nie" (Matth. 22 : 29).

Die kerk is dus geroepe om wag te staan by sy Belydenis en teenoor homself in die eerste plek en teenoor andersdenkendes in die tweede plek verantwoording te doen. Dit is geen maklike taak en mag ook nie ligvaardig geskied nie. Berkouwer se woorde moet sekerlik ter harte geneem word: „Verdedigen is een verantwoordelijke zaak! Men zal er zich niet voor schamen en men aarzele niet. Maar men zij voorzichtig en wete, wát men verdedigt als onaantastbare uxarheid Gods".

Teenoor hierdie hehoudende konfessionele standpunt moet ons helaas spreek van 'n ander geestesrigting, een wat in die hele aanpak van die moeilike probleem van interkerklike verhoudinge. waar die belydenis tog sekerlik in gedrang kom, 'n rigting inslaan wat irenies van aard is.

Ons wil in die eerste plek verwys na die onlangse werk van ds. H. Volten, „Rondom het belijden der kerk”. Hierdie studie het nnspraak verwek, nic vanweë sy prinsipiële bena- 
dering van die belyde van die kerk nie, maar juis om ' $n$ al te maklike voorstel tot oplossing van interkerklike verhoudinge en aanpassing van die Belydenis om te kom tot kerklike eenheid. Volten sal bekend staan as die man wat ,reductie der belijdenis" aan die hand doen. Hy wil 'n belydenis want, so sê hy self, die belydenis is, hoe korrigeerbaar ook, die rigtinggewende woord wat oor waarheid en dwaling die oordeel vel en uitmaak wat die leer is. Maar dan kom die vraag: hoe oorkom ons die kerklike geskeidenheid? Hoe kan die belydenis saambind? Hy beweer dat daar vier oplossinge is wat ons kortliks wil noem: die van die biblisisme, wat net met Gods Woord volstaan en elke vorm van belydenis vermy; die uniforme belydenis nl. dat daar slegs één ware belydenis is en al die ander is vals; die pluriforme kerk, elkeen met eie belydenis, waarvan elkeen minder waar en meer vals is, maar waar eintlik van valsheid geen sprake meer kan wees nie. Dit is volkome normaal dat daar meer kerke as één is, en dit is volkome normaal dat daar meerdere en mindere suiwerheid is in belydenis. Selfs die mins suiwere kerk is nog 'n Christelike kerk. Die laaste oplossing is dan reduksie. Die pluriforme bestaan van die kerk moet te bowe gekom word deur inkorting van die Belydenis.

Reduksie gaan uit van die standpunt dat daar fundamentele en nie-fundamentele stukke is in die Belydenis. Die vraag is natuurlik of dit ' $n$ bewysbare en aanvaarbare stelling is. Dit skyn my gevaarlik, want 'n sogenaamde nie-fundamentele gedeelte van die Belydenis kan op 'n gegewe moment fundamenteel wees. As dit nie fundamenteel is nie, waarom is dit dan in 'n uiters gekonsentreerde Belydenisstuk opgeneem? Volten antwoord hierop deur daarop te wys dat elke belydenis tog al klaar ' $n$ reduksie is, want uit die Woord van God is dit gereduseer. Dit skyn 'n argument te wees, maar is inderdaad 'n gevaarlike afwyking. Reduksie beteken afleiding en elke afleiding bring bekorting mee, maar is 'n menslike daad. Veeleer sou 'n mens die woord distilleer, konsentreer, gebruik as reduksie. Volten hou egter vol dat alle leerstukke nie van gelyke waarde is nie, en hy pas konsentrasie toe op die leerstukke as sodanig en wil daaruit verwyder dit wat hom toeskyn as ' $n$ appendix, wat wel misbaar is. Willekeurige snywerk word nie begeer nie, en dit sou miskien die allerbeste wees 
as alle kerke die Drie Formuliere van Enigheid aanvaar. Maar dan sou ons één kerk wees. Dit kan nie gebeur nie en tog moet die eenheid nagestreef word.

Wat begeer Volten? Hy spreek dit ondubbelsinnig uit: „Ik wil een modaliteiten-kerk”. Daar moet dus één kerk bestaan met 'n veelvuldige aantal modaliteite. Die verskille tussen die modaliteite sal menigvuldig wees as die bestaande Geloofsbelydenis gehandhaaf word. Reduseer daarom die Geloofsbelydenis tot 'n paar fundamentele stukke en siedaar die oplossing. Die pluriformiteit word dus gehandhaaf, maar net hinne die een kerk.

Hier is nog nie gesê hoe voorgestel word om te werk te gaan in die proses van reduksie nie. Daar word wel gedagtes gegee, juis al in die sogenaamde fundamentele en nie-fundamentele leerstukke. 'n Mens kan dit natuurlik ook reduseer soos die Wêreldraad van Kerke en slegs spreek van Jesus Christus, God en Saligmaker. Dan sou 'n mens dieselfde warbeeld verkry as wat hierdie Raad vertoon, met die baie modaliteite wat hy herberg. Inderdaad is dit éen huis wat teen homself verdeeld is. Die organisme van die Belydenis laat homself ook nie só maklik reduseer nie. Ons noem slegs die voorbeeld, soos wat die Heidelbergse Kategismus dit weergee, juis omdat dit hier gaan om Jesus Christus. Vraag 30 vra: Glo hulle dan sok in die enigste Saligmaker Jesus, wat hulle saligheid en welsyn by die heiliges, by hulleself of êrens anders soek? Sou dit 'n geregverdigde vraag wees? Sal ons hom by eventuele reduksie weglaat? Dit skyn so, want hier word duidelik teen verskillende modaliteite te velde getrek, nie net teen Rome nie, maar nok teen elke Remonstrantse neiging waarin die menslike bemiddeling hooggeskat word, elke humanisme wat rekening wil hou met eie prestasie en dit wil laat meetel in die Goddelike heilsplan. Die antwoord hier gegee is: „Nee; maar hulle verloën met die daad die enigste Heiland Jesus, ofskoon hulle met die mond in Hom roem ..." Nee, inderdaad, 'n mens kan nie Jesus se Naam noem en dan met alle vreemde leerpraktyke van selfverlossing Hom weer likwideer nie.

Vanuit ' $n$ ander oord kom 'n ietwat vreemde gedagte in verband met die kerk se Konfessie juis waar dit die ekumene betref. Ons verwys na 'n opmerking van prof. Nauta, wat nogal instemming ontvang het, selfs van Brillenburg-Wurth. Dit het 
ook gegaan oor interkerklike verhoudinge. Prof. Nauta wys daarop dat in die kerkgeskiedenis van heel vroeëre tye bv. die Reformasietyd, die kerk hom veel meer apodikties uitgespreek het as wat vandag die geval is. Daar is veel makliker omgegaan met die terme waar en vals. Ons sou vandag die Baptistiese kerke nie as vals bestempel nie, maar as dwalende, wat die Doop betref. Nou wil Nauta van reduksie van die Belydenis niks weet nie, maar hy bied 'n oplossing aan vir die oorbrugging van die waar-vals dilenma. Daar kan nooit sprake wees van relatiwisme in ons Belydenis nie en alle relatiwisme moet vir eens en altyd afgewys word. Maar ons moet tog erken dat ons Belydenis 'n relatiewe karakter dra, vanweë die gebrekkigheid van ons menslike verstand en die swakheid van ons geloofsinsig. Daar is soveel belemmerende faktore wat dit vir ons moeilik maak om die volle Woord van God in ons Belydenis saam te vat. Die relatiwisme is vreemd aan ons, maar relatiwiteit eie aan ons. Prof. Nauta sê nou dat dit wat ons gedwing word om te erken, nl. dat daar onvolkomenheid is, ons eie kerk nie die karakter kan gee van 'n suiwere ware kerk nie. Jy self word eintlik gedwing om te bely dat dit eie aan die kerk onder die sonde is om te $d w a a l$. Dieselfde reg moet ook aan ander kerke gegee word. Nauta noem dit „die reg van dwaling".

Ook hierdie standpunt moet ons beoordeel, want dit bring ons op 'n gans ander vlak te staan as die tot nog toe bewandelde. Die vraag is, as ons by ander die reg van dwaling moet erken, hoe kan ons ooit mekaar tot bekering en berou, tot reformasie roep? Word hier nie te veel prysgegee nie? Hierdie erkenning sluit dan ook in dat ons mekaar maar moet duld. As hierdie reg om te dwaal sou insluit dat ons mekaar die reg om te sondig nie moet ontsê nie, sou dit werklik 'n onreformatoriese reg wees, 'n onskriftuurlike. Al wat dit sou moet omhels moet slegs wees dat geen kerk hooghartig teenoor 'n ander mag staan nie, maar dat ons vir mekaar tot voete en oë moet wees.

In hierdie verband klink die woorde van Polman versigtiger as hy spreek van "tolerantie ten opzigte van de formulering", en Berkouwer sluit hierby aan as hy spreek van „de voortgang van het belijden". Inderdaad word voortdurend nuwe eksegetiese lig gewerp op Skriftuurplekke waarop die Belydenis steun. „Daarom kunnen er in nuwe tijden vanuit 
het altijd uitstralend licht der Schrift verschuivingen optreden, die alleen in het licht kunnen worden getoetst. Slechts in voortdurende gemeenschappelijke worsteling om dat licht van het evangelie op te vangen, zal er van trouw kunnen worden gesproken en zal het mogelijk zijn onszelf en anderen te toetsen op de gehoorzaamheid aan het belijden" (Ger. Theol. Tijdschr. Febr. 1963, p. 22, 23).

Berkouwer gee hom goed rekenskap van wat trou aan die Belydenis van elke ondertekenaar vereis. Sou dit gerade wees om telkens, as 'n ondertekenaar na grondige eksegese en Skrifverklaring, aanvaarde simbole nie meer in dieselfde bewoording kan aanvaar nie, sy beswaar bekend te maak by kerklike instansies? Sy konklusie is: „De formule bedoelt juist de weg open te houden, de weg waarop de kerk luisterend haar weg vervolgt" (G.T.T. 28). Hiermee kan ons ons vereenselwig, want daar word op dieselfde fondamente voortgebou. Die Belydenis het tot hiertoe hom vasgekoppel aan die Evangelie en het telkens stellig beweer dat hy alleen eksaminabel bly aan die Skrif. Trou ann die Belydenis beteken trou an die Skrif. Slegs dan is daar ontrou, wanneer 'n konflik met die Belydenis ook 'n konflik met die Skrif meebring. Met ander woorde, ons wil geen vergoddeliking van die Belydenis in die sin dat dit gekanoniseer word as afgeslote, as volkome en finaal outoritatief nie. Daar is historiese bepaaldhede, daar is onvolkomenheid in ons menslike formuleringe, daar is voortgaande Skrifondersoek en daarom moet daar wees wat ons kan noem oopheid tot nadere formulering.

Ek glo dat ons, samevattend, op die vraag: watter waarde ken ons toe aan ons Belydenisskrifte? kan antwoord dat die Belydenisskrifte sekerheid en stelligheid gee en dat ons dit nie moet relativeer nie. Dit is ook nie gedoen nie en die feit dat ons konfessies op talle plekke gestaaf word deur die Skrifhewys, het daartoe bygedra. Die Konfessies dra daartoe by dat ons wel kan spreek en moet bly spreek van kerklike geskeidenheid, waarmee ons die vinger lê op 'n inherente verskil in belydenis, op ' $n$ andersoortige belydenis. Dit hoef nie uit te kom in 'n totaal-andersheid, in sover as wat daar niks saamstem met die eie belydenis nie. Ons kan bv. by Rome spreek van ' $n$ onfeilbare dogma en van 'n onfeilbare kerk. Hierdie konfessies tesame met ander, is nie gradueel verskillend van 
die van die Gereformeerde Konfessie nie, maar is wesensmatig. Hier het ons te doen met kerklike geskeidenheid.

Daar is egter ook kerklike verskeidenheid, waar verskillende kerke openbaringe is van die één Christelike kerk, met dieselfde belydenis. Vir die kerklike verskeidenheid is die bely. denis ook van uitnemende belang, sodat verskeidenheid duidelik van geskeidenheid onderskei kan word. Verskeidenheid word nie bepaal deur die Belydenis nie, omdat hier geen belydenisverskille kan wees nie. Sodra as daar belydenisverskille kom, het ons te doen met geskeidenheid. Die kerk is dus één in sy verskeidenheid, omdat hy verskeie is in taal, volk, aardrykskundige ligging ens. Met verskeidenheid kan ons vrede hê. omdat daar geen versteurde verhoudinge is nie. Die verskeie kerke moet hulle eenheid vertoon deur in één kerkverband te staan.

Anders staan dit egter met die geskeidenheid. Dit is 'n sondige verskynsel, want verskeie kerke het verskeie belydenisse. of verstaan mekaar nie meer nie, al het hulle dieselfde helydenisgrondslag. Prof. Snijman sê hiervan: „Hier is dit 'n versteurde broederlike verhouding. Maar al is dit 'n versteurde broederlike verhouding, dit bly 'n broederlike verhouding wat versteur is". Geskeie kerke mag mekaar nie maar net duld nie, mag ook nie vrede hê met die geskeidenheid nie, mag nie mekaar verkleineer en verag nie. Hulle mag egter ook nie die verskille tot geskille laat ontwikkel nie. Die verskille mag ook nie geringgeskat word nie. Wat dan? Ons haal weer prof. Snijman aan: Ons moet ,soos manne wat glo in die eenheid van die kerk bymekaar kom, en moedig die verskille onder oë sien, en biddend met mekaar worstel om die renheid van die kerk, warin ons glo, 'n eenheid gegrond op die waarheid. So hou ons in die geloof vas aan die eenheid van die kerk ook in sy geskeidenheid".

Op die vraag: watter rol speel interkerklike verhoudinge by die opvatting oor die Belydenis? moet die antwoord een van uiterste versigtigheid wees. Ons het telkens aangedui dat menslike formuleringe sekerlik inadekwaat is, dat dit in die denke van die tyd geskied, dat belydenisskrifte nie vereer moet word as onveranderlik nie, dat dit slegs logies sal wees dat by voortgang van die Skrifverklaring daar behoefte kan kom tot nadere verklaring. 
Binne die kerklike verskeidenheid sou dit niks anders as 'n gelowige roeping wees om voortdurend verantwoording te doen van die Belydenis wat die aanvaarde grondslag is nie. Hierdie verantwoording sal sowel positief as negatief moet wees, en dit sal lei tot uitbouing en tot afwysing. In die gees van die Belydenis wat waaragtig Skrifgegrond wil bly en in alles slegs Skrifmatige taal wil spreek, kan voortgebou word. So bou ons dan op gelegde fondamente. Hy wat langs die fondament wil bou of fondamentloos wil voortbou, benadruk sy begeerte tot geskeidenheid. Hy moet geroep word tot terugkeer, tot reformasie, tot regte fondamente.

P.U. vir C.H.O.

S. P. van der Walt. 